\title{
LEO XIII ON CHURCH AND STATE: THE GENERAL STRUCTURE OF THE CONTROVERSY
}

JOHN COURTNEY MURRAY, S.J.

Woodstock College

In the whole Leonine corpus there are some ninety-seven documents which are relevant to the problem of Church and State. Perhaps twenty are of major importance. ${ }^{1}$ What follows is an attempt to outline the structure of the doctrine which is evolved in this whole mass of documents, to indicate the themes which are developed, the relative weight of emphasis given to each, their relationships with each other, and their appositeness to the historical problems of the time.

The historical situation is important. Leo XIII did not compose his doctrine in the midst of academic quiet, in the leisure of a library, sealed off from the swirling struggles in the marketplace of the late nineteenth-century world. Rather, he hammered it out as the head of an embattled Church, which was under an attack more radical and total than any that the Church had previously encountered in history.

\section{THE CHURCH AND THE SECT}

What initially strikes the student is Leo XIII's clear diagram of the organized forces in conflict. Briefly, the struggle is between "the church" and "the sects." These "sects" are not academic or university groups, but activist parties; they are in quest of, and have largely attained, political power. And their quest and use of power has a definite goal, to effect a radical transformation of traditionally Christian society in its structure and its substance. Over against the sects there

${ }^{1}$ Inscrutabili (1878), Quod apostolici muneris (1878), Arcanum (1880), Diuturnum (1881), Etsi Nos (1882), Nobilissima Gallorum gens (1884), Humanum genus (1884), Immortale Dei (1885), Jampridem Nobis (1886), Quantunque Le siano (1887), Officio sanctissimo (1887), Libertas (1888), E giunto (1889), Sapientiae christianae (1890), Dall' alto (1890), Rerum novarum (1891), A u milieu (1892), Inimica vis (1892), Gardien de cetle foi (1892), Praeclara gratulationis (1894), Graves de communi (1901), Pervenuti (1902). In many other documents there are brief but important references to one or other aspect of the problem. Citations are usually made from Acta Sanctae Sedis. A fuller edition is Leonis Papae XIII Allocutiones, Epistolae, Constitutiones, 7 vols. (Paris: Desclée, 1887-); it is cited as "Desclée." An even more inclusive edition is Lettres Apostoliques de Léon $X I I I$, Encycliques, Brefs, etc., Texte latin avec traduction française, 7 vols. (Paris: Maison de la Bonne Presse, s.a.); it is cited as "Bonne Presse." 
stands the Church, as a spiritual authority, and as the community of the faithful. Leo XIII conceived this community to be importantly organized into the territorial communities of traditionally Catholic faith and culture. He accepted the historical concept of the "Catholic nation" as Europe had brought it forth. ${ }^{2}$ And he aligned the "Catholic peoples," thus nationally organized, with himself in the struggle against "the sects."

The sects in question were not, of course, the various Protestant bodies. For Leo XIII Protestantism was not the Enemy, capitalized. He was not of the sixteenth or seventeenth century. It is true that there are three documents which protest against Protestant evangelism within the city of Rome, and against its alliance, dubiously complimentary to itself, with the bitterly antireligious Italian government. ${ }^{3}$ And there are conventional references to the Protestant Reform as an historical and doctrinal force dissolvent of Christian faith and culture. However, a new historical note was sounded by Leo's view of Protestantism in the perspectives of the movement whose stirrings he sensed, especially toward the end of his reign, "a unitive movement [which] preoccupies and governs the contemporary generation," in consequence of its growing experience of a "living sense of brotherhood."4

Leo XIII was the first Pope, as far as I know, to use the expression, "fratelli nostri separati da noi."

${ }^{2}$ These are some of the mentions made of the concept: "uno stato cattolico ... cattolica Italia" (Ci siamo, June 1, 1879); "in regnis catholicis," among which is Bavaria (Officio sanctissimo, Dec. 22, 1887); "la Spagna... nazione cattolica" (Quantunque Le siano, June 15, 1887); "la cattolica Spagna" (Non è questa, May 3, 1888); "France, nation catholique" (Au milieu, Feb. 16, 1892); "in civitatibus catholicis" (Libertas, June 20, 1888); "gentes catholica religione dotatas," the reference being to Poland (Caritatis, March 19, 1894). It is a curious thing that Leo XIII does not seem to have given any attention to the vice of nationalism, the force that swelled to such power and wrought such destruction in the nineteenth century, both in society and in the Church.

${ }^{3}$ Letters to the Cardinal Vicar of Rome, June 26, 1878; March 25, 1879; August 19, 1900 (in this letter the Pope uses the technical legal term, "religion of the state," its single occurrence, to my knowledge, in his whole corpus: "sects of all kinds [are] singly bent on plucking from the soul of the people that religion which was declared the religion of the state and which constitutes the principal object of their love and of their cult" (Bonne Presse, VI, 142). Elsewhere too there are references to Protestant missionary activity in Rome.

4 Allocution, La rinnovata, March 1, 1897 (Desclée, VI, 265).

5 Ibid., p. 264; there is a reference in the letter to the English bishops, Spectata fides (Nov. 27, 1885), to the residue of the "patrimony of Christian wisdom" among the dissidents. 
the "sanior pars hominum" upon whom he counted for aid against the laicist revolution. They were likewise among "the good and sensible Frenchmen" who, whatever their other differences, would not be "dissident" from Catholics in regard of the proposition that "religion is the interior and exterior expression of the dependence we owe to God on title of justice," that it is the necessary foundation of the moral sense and therefore the basis of social order, and that there consequently exists a common civic duty to defend religion against "an atheist school, which in despite of the protests of nature and of history, is endeavoring to dismiss God from society." As the intimate essence of "modernity" appeared in unambiguous form and the basic lines of conflict were drawn between it and the tradition, Leo XIII made the first firm, if unaccented, suggestion of that alliance among all men of good will which Pius XII later, and rather unsuccessfully, urged upon the Christian world. The alliance was suggested by the very configuration of the forces in the field, as first apparent to Leo XIII.

The sects which Leo XIII identified as the Enemy were the organized adherents of the new political religions whose appearance on the national and international scene was perhaps the most formidable phenomenon of the nineteenth century. And the Sect of sects was, in Leo's view, the Masonic Order. The Pope was not indeed unaware that a new Zeitgeist was on its conquering march, that a new climate of opinion and feeling had rolled in from many quarters upon the world, especially upon the European world which was closest to him. ${ }^{8} \mathrm{He}$ speaks in his first Encyclical of a "certain mortally infectious disease which is quietly spreading through the inmost organs of human soci-

${ }^{6}$ Encyclical, Humanum genus, ASS, XVI (1883-84), 428.

${ }^{7}$ Encyclical, A u milieu, ASS, XXIV (1891-92), 519, 520.

${ }^{8}$ A most suggestive historical account of the "modern" phenomenon, whose origins were in the early Middle Ages, has recently been given by Eric Voegelin, The New Science of Politics (University of Chicago Press, 1952), especially chap. IV, "Gnosticism-the Nature of Modernity." This type of study is a valuable corrective of the Catholic homiletic commonplace - a sort of myth-according to which error and evil first burst upon the world with the Reformation. One would not learn from Leo XIII, for instance, that there had been aught but truth, goodness, and order before the Reformers; just as one would not learn from him that there was aught but error, evil, and disorder in the nineteenthcentury movement toward political freedom. His corpus belongs to that stream of literature on the decline of Western civilization which began in the eighteenth century. In any event, it must be remembered that the Pope is the judge of the validity of ideas in their nakedness; he is not a research scholar interested in the tortuous path of ideas through history, during which they acquire ambiguous clothing. 
ety."' But it is characteristic of his thought that the Masonic sect should be identified as the source and carrier of this disease. The identification is made in the first year of his pontificate in the Encyclical, Quod apostolici muneris (December, 1878)..$^{10}$ It is maintained with increasing emphasis throughout his long years of teaching. And the emphasis is still marked in his last important statement, the Apostolic Letter, Pervenuti, in March, 1902. There are two Encyclicals entirely devoted to the Sect, Humanum gemus (1884) and Dall'alto (1890); there is one Apostolic Letter, Inimica vis (1892). There is also an Instruction of the Sacred Congregation of Bishops and Regulars (1889), and a Letter to the Italian people (1892). ${ }^{11}$ Elsewhere the references are frequent; they occur regularly whenever there is question of affairs in Italy and France.

The Pope accepts the theory of a "vast conspiracy,"12 international in scope, with a clearly defined goal and a definite strategy. The Sect is cosmopolitan, everywhere operative: "a wicked sect, spread throughout the world." 13 Its national branches are linked by a "secret pact" $;^{14}$ their unity and their activism are such as Catholics themselves might well emulate. ${ }^{15}$ However, the "destructive force" of the Sect "has for a long time been bent especially against the Catholic nations." ${ }^{16}$ In France, "all the evils which overwhelm you [the French people] have as their origin the hatred of a caliginous society, the irreconcilable enemy of the Catholic faith." 17 The same is true of Italy, where "the

Inscrutabili, ASS, X (1877-78), 586.

${ }^{10}$ Socialism, Communism, and Anarchism are here all put together as one sect, whose members "are spread throughout the world [i.e., the Pope's world, which was Europe; that there was exceedingly little, if any, of this kind of sectarianism in the United States at the time does not come within the Pope's reckoning], and most closely allied with one another by a wicked pact" (ASS, XI [1878-79], 369). This composite sect, the Pope goes on to say, had its origins in, and then stood under the leadership of, the secret societies, Masonic in type, first condemned by Clement XII (1730-1740). This may seem to be a rather rapid generalization about the origins of European Socialism.

11 The letter to the Italian people, in French translation, is in the edition Bonne Presse, III, 164 ff.; the letter is dated Dec. 8, 1892, the same day as the Letter, Inimica vis, to the Italian Episcopate.

12 Encyclical, Au milieu, ASS, XXIV (1891-1892), 519.

${ }^{13}$ Instructio S. Congreg. Episc. et Regul., July 18, 1889 (Desclée, III, 262).

${ }^{14}$ Allocution, Nous ne pouvons, April 15, 1901 (Bonne Presse, VI, 233).

${ }^{15}$ This is a frequent theme; cf. Encyclical, Etsi Nos, Feb. 15, 1882 (Desclée, I, 272). It it usually joined with a reproach to Catholic apathy, especially in Italy.

${ }^{16}$ Letter, Praeclara gratulationis, ASS, XXVI (1893-94), 713.

${ }^{17}$ Letter, Vos lettres, ASS, XXV (1892-93), 269. 
satanic hatred of the sects takes as its most particular object the city of Rome."18

The dynamic of the sect is "hatred of the Catholic Church, of its divine mission, and of the spiritual power of its supreme Head." ${ }_{19}$ It has launched a "systematic war against everything that is Catholic." ${ }_{20}$ And the strategy of the war is patent. The first step was to strip the Roman Pontiff of his temporal power and thus cripple the freedom of his spiritual authority. ${ }^{21}$ The next assault is on this spiritual authority; the sectaries are in fact planning the destruction of the Church herself, as a power and as a people. Their effort is to "tear the Italian people away from that faith" which was their traditional glory and prosperity; "22 "to annihilate Christianity in France", ${ }^{23}$ "to alienate whole societies from God." 24

There is too the social objective, both negative and positive. The goal is "to drive God out of society," to "strip society of its Christian form," 25 to "cancel from the nation [Italy] its religious and Christian stamp." ${ }^{26}$ The sectaries are "pursuing their evil enterprise, which is to make society (as they put it) 'laic,' that is, a land of exile from Christ the Lord [a Christo Domino extorrem], and to deprive society of the wonderful benefits of the Christian redemption." ${ }_{27}$ More positively, their goal is to establish in society "a new religion, in which divine worship will be accorded to human reason, under contempt for the sovereignty of the immortal God." 28 Indeed, these men "have conceived the altogether fixed idea of altering the destinies of the privileged city [Rome], of transfiguring it, of turning it pagan; as they put it in their jargon, the idea is to bring into existence a Third Rome, whence as from its center there would radiate a Third Civilization." ${ }_{29}$

${ }^{18}$ Letter, Fra le molteplici, Dec. 18, 1889 (Desclée, III, 294); cf. the Allocution, In molte occasioni, Oct. 24, 1888 (Desclée, III, 175).

${ }^{19}$ Allocution, I singolari benefici, Dec. 24, 1888 (Desclée, III, 188).

${ }^{20}$ Ibid., p. 187.

${ }^{21}$ Letter, Gratam scilo, March 31, 1889 (Desclée, III, 232). The Pope constantly views the spoliation of the temporal power in the perspectives of the sectarian conspiracy.

22 Allocution, Quod nuper, ASS, XXI (1888-89), 708.

${ }^{23}$ Encyclical, Au milieu, ASS, XXIV (1891-92), 519.

${ }^{24}$ Allocution, Quod nuper, ASS, XXI (1888-89), 706.

${ }^{25}$ Letter, Praeclara gratulationis, ASS, XXVI (1893-94), 713.

${ }^{26}$ Encyclical, Dall'alto, ASS, XXIII (1890-91), 195.

${ }^{27}$ Letter, Novae condendae, ASS, XXV (1892-93), 460.

${ }^{28}$ Instructio S. Congreg. Episc, et Regul., July 18, 1889 (Desclée, III, 268).

${ }^{29}$ Letter, Le insolite, Oct. 8, 1895 (Desclée, VI, 99). 
The chosen instrument of these grandiose designs, national and international, is the acquisition of governmental power, or at least of the favor of government:

This caliginous sect ... the permanent personification of the Revolution, ... constitutes a sort of society relourné; its purpose is to exercise a hidden suzerainty over recognized society, and its reason for being consists wholly in making war upon God and His Church.... It embraces in its immense nets almost the totality of nations; it strikes relationships with other sects, whose movements it controls by hidden strings; it first attracts and then holds on to its members by the bait of the advantages it can procure for them; it bends governments to its designs, at times by promises, at times by threats. This sect has managed to infiltrate into all classes of society. It forms, as it were, an invisible and irresponsible state within the legitimate state.... It protests that it has no political aims, but in reality it exercises the most profound influence on the legislative and administrative life of states. And although it verbally professes respect for authority and for religion, its supreme purpose (as its own statutes bear witness) is the extermination of the sovereignty [of the state] and of the priesthood [of the Church], in which it sees the enemies of freedom. ${ }^{30}$

In the same vein: "The most disastrous thing is that, wherever the Sect gains a foothold, it infiltrates all the ranks and institutions of society, with the purpose of reaching the top and gaining control." ${ }_{31}$ Again, "in order to realize their own aspirations they find in the depositaries of public power avowed sponsors and docile instruments." ${ }_{32}$ "They insinuate themselves with men of government, with this end in view, to have them as powerful allies and assistants in the work of oppressing Catholicism." "' ${ }^{33}$ And the success of the Sect has been considerable: "By thrusting itself either audaciously or deceitfully into all orders of society, it has begun to achieve such power that it seems almost able to have its own way with whole peoples." ${ }^{34}$ The success in

${ }^{30}$ Letter, Pervenuti, ASS, XXXIV (1901-02), 526-27; the Pope more than once designates the Sect with the ironic epithet, "tenebrosa," the reference being to its secrecy as well as to its pretense to "enlightenment."

${ }^{31}$ Letter, Praeclara gratulationis, ASS, XXVI (1893-94), 713; this Letter asserts the Sect to be the second greatest danger to human unity, after the loss of the true concept of the unity and freedom of the Church.

32 Encyclical, Dall'alto, ASS, XXIII (1890-91), 196.

${ }^{33}$ Encyclical, Humanum gemus, ASS, XVI (1883-84), 428.

${ }^{34}$ Ibid., p. 419. 
Italy has been particularly signal. In the light of the facts "it is becoming more and more evident that the master-idea which presides over the course of public affairs in Italy, as far as religion is concerned, is the realization of the Masonic program." ${ }^{35}$ And in France the arrogance of this "faction, furious against the Church," has reached the point where "it admits no right in public affairs except for itself, and sacrifices the supreme interests of society to its own inveterate hatreds." ${ }_{36}$

These few texts suffice to indicate the importance of Masonic sectarianism in the eyes of Leo XIII. In Humanum genus and in the other documents cited, the whole theme receives its full development-the secrecy of the sect and its later overtness, its organization, its affiliations (especially with the Socialist sect), its activism, the "dogmas of the boldest sort of impiety" that underlie its program, and above all the revolutionary intent: ". . that which is ultimate in their designs, namely, completely to overthrow that whole system of religion and of politics which the Christian way of life produced, and to construct in accord with their own way of thinking a new system, whose foundations and laws would be derived from the essence of Naturalism." ${ }^{77}$ Finally, there is everywhere emphasis on the Sect's quest of governmental power as the chosen instrument of its design to build a new kind of state and fashion a new kind of society.

To an American, of course, a controversy with this structure seems alien, and altogether "European" in the bad sense of the word, for the particular reason that we are not accustomed to attribute such ideological importance or such far-reaching social and religious significance to the thing called "government." In any event, it is not to the purpose here to examine the evidence in support of this thesis that international Masonry was the Enemy, who was seeking to further the ends of revolution by control of government. The element of organized conspiracy on an international scale could perhaps be exaggerated. But the fact of Masonic influence on the governments of France and Italy was altogether patent. The rather spectacular propagandistic activities of Lemmi, the Grand Master, and the consistent political program of Crispi, also a Mason, must have been particularly convincing to the

\footnotetext{
${ }^{35}$ Encyclical, Dall alto, ASS, XXIII (1890-91), 197.

${ }^{36}$ Letter, Vos lettres, ASS, XXV (1892-93), 267.

${ }^{37}$ Encyclical, Humanum genus, ASS, XVI (1883-84), 421.
} 
Pope. In any event, there are several reasons for adducing Leo XIII's diagram of the organized forces in the field, the Church and the Sect. First, this diagram, so strongly and repeatedly drawn, is the second characteristic of his thought that serves to situate it in the nineteenth century (the first, of course, is the Pope's absorption in the Roman Question). No such diagram would correspond to the realities of the new phase of the perennial struggle between the Church and "the world," through which we ourselves are now living. The Grand Orient, I take it, has had its day. A force much more formidable in its faith and in its organization has moved into the center of the field. And the lines of conflict have been importantly altered.

Secondly, Leo's diagram (the Church vs. the Sect) is still more important in that it furnishes a considerable part of the explanation for another outstanding characteristic of his thought. I mean his incessant preoccupation with government, or rather, since he thinks normally in personal terms, with governors, the principes. They stalk steadily through his pages. Other reasons for his preoccupation with them will come up later. To some extent the reasons are doctrinal; to a greater extent they are historical. The Church had entered the decade of the 1850 's in close collaboration with all the dominant interests in society; in the 1870 's she stood isolated and alone. And the change was related to all the important movements of the time, intellectual, economic, and political. Leo XIII made it his supreme task to end this isolation.

His intellectual policy lies somewhat outside our scope, though it will be mentioned later, for the purpose of putting his political policy in perspective. It consisted in promoting the renewal of learning, religious and secular, within the Church, on all levels. The purpose was primarily to further the defense and development of the Christian tradition; the purpose was also to create the possibility of a fruitful dialogue with the new intellectual community, and the further possibility of intelligent political and social action. His economic policy shows in his assumption of the leadership of the Catholic movement which was afoot chiefly in the lands north of the Alps, looking to a Christian solution of the Social Question. But his initial cardinal policy was political, directed at ending the alienation between the Holy See and secular governments. 
This policy of approach to government was part of his cardinal policy of concordia. But a special reason for the policy is supplied by the similar policy of the Sect. The question, "Quis custodiet custodes?", was a vital question in the historical context. The obverse of government's alienation from the Church was its friendliness with the Sect. The discord between the action of government and the spiritual purposes of the Church was made more dangerous by the accord between this governmental action and the laicist purposes of the Sect. In the circumstances, therefore, it was of first importance to shatter the accord and to resolve the discord. ${ }^{37 a}$

To this end Leo XIII tirelessly addresses himself to government. His argument is that the existent relationships with the Sect will in the end be disastrous to government's own interests; that these interests - notably, the strength and stability of government itself-require harmonious relationships with the Church. The place of this argument in the structure of Leo XIII's total case will later be indicated. It is sufficient for the moment to have noted that the prominence of the principes in the policy of Leo XIII was closely paralleled on their prominence in the policy of the sectaries. There was urgent need to wean government away from its alliance with sectarian purposes and to win its alliance with the human and Christian purposes of which the Church, as an authority and a people, is the representative.

At least a mention must here be given to two other forces in the field. There was the negative force of the Catholic masses, religiously untutored and socially inert, especially in Italy, where the rule of the non expedit still held. And there was the divisive force of the spirit of faction among the Catholic élite, especially in France and Spain, and to a lesser extent in Germany. But the problem created by these forces, and their influence on the thought and policy of Leo XIII, must be left for later discussion.

Finally, it may be interesting to note how the Leonine diagram, the Church vs. the Sect, reflects in its own way the famous historical doctrine of les deux Frances. It is a historical commonplace that the Revo-

37a "It would be highly in accord with civil prudence, as well as necessary for the common safety, that rulers and peoples should join forces with the Church to defeat the attacks of the Masons, instead of joining forces with the Masons to ruin the Church" (Humanum genus, ASS, XVI [1883-84], 429). 
lution split France into two Frances, and that she has never really recovered from the scission. In the same way there have arisen two Italies and two Spains. ${ }^{38}$ There is the France, Italy, and Spain that have remained Christian and have striven to sustain continuity with their history. And there is the France, Italy, and Spain that have gone sectarian and have attempted to inaugurate a new history. Neither of the two has ever quite succeeded in winning victory over the other and thus overcoming the division. But both sides seem to have been long agreed that the way to victory is the same for each of them, namely, control of the government. This has been particularly true of Spain. But the result has been tragic. Given the irreconcilable twoness, no government, whether Catholic or sectarian, could succeed in being representative of the people. And the endless argument goes on (again particularly in Spain, where the edges of the twoness have never been blunted, as in France) as to what is the "real Spain"? Or, as the question was put in early Revolutionary France, "Who belongs to the Nation?" It is this twoness which has rendered ambiguous, and to that extent invalid, the great historical concept of "the Catholic nation." Nonetheless, Leo XIII was prepared to defend the concept. Its history was real enough, whatever its contemporary reality may have been.

\section{THE STRUCTURE OF THE CONFLICT}

More important than the constellation of forces in the field was the conflict of ideas represented by these forces. The basic conflict concerned the order of reality itself - the nature of truth, the norm of morality, the scope of reason, the meaning of freedom, and the mutual relations of freedom and authority, liberty and law. On this level a naturalistic rationalism challenged the Christian metaphysic. The disagreement was over the very nature and destiny of man. However, this conflict was not simply an affair of the schools, an academic argument. It was also strongly historical, a clash between two sets of ordering ideas, each of which sought expression in history, on the plane of earth, in the existential life of man. Hence there was a second conflict which concerned the structure of politics. The sectarian view upheld that monism of law and social power to which the severely contracted ra-

${ }^{38}$ Leo XIII speaks in Dall'alto of the "profound division between official Italy and the great part of Italians who are truly Catholic" (ASS, XXIII [1890-91], 203). 
tionalist view of nature and reason logically leads; the traditional view contended for the dual order of authorities, laws, and societies, and for their hierarchy, as demanded by the differentiated Christian metaphysic, based on nature and grace, reason and revelation. The issue here concerned the organization and direction of society. But the issue in this controversy involved more than the forms of societal structure, organization, and direction. At bottom, the spiritual substance of society was at stake.

Hence the third controversy concerned this substantive matter. The antagonist here was laicism, the new political religion which sought to dictate the structure of society, to determine the ends of politics, to ensoul all the institutions of man's social life, and indeed to be the author of whatever salvation man might hope for. Over against laicism stood "Christianity" in the traditional sense, as implying that the Christian faith is not simply an affair of the individual soul or of the sacristy, but the architectural principle of human society, the wisdom directive of politics to its true ends, the animating substance of social institutions, and the necessary spiritual armature even of that body of rational truth which is "the common patrimony of the human race, on which, as on a solid foundation, morals and justice, and all sacrednesses, and even human social unity itself must rest." ${ }_{39}$ In brief, this third conflict was between the pregnant laicist concept of "separation" and Leo XIII's equally pregnant concept of "harmony," as applied to the two powers, and at a deeper level, to the two societies, spiritual and temporal.

This last controversy was the crucial one; it englobed the other two. And it was further complicated by the fact that the sectarian concept of "separation" was in the first instance an engine of historical destruction. It implied the violent disjunction by new legislative action of the particular mode of connection which had historically been established between the two powers and the two societies. "Separation" looked to the dismantling of existent legal institutions; more profoundly, it looked to the consummation of a social apostasy..$^{40}$ As laicist philosophy

${ }^{39}$ Encyclical, Libertas, ASS, XX (1888-89), 606.

${ }^{40}$ Early in the first year of his pontificate Leo XIII joins the two notions: "the announced separation and the planned apostasy of present-day society from Christ and from His Church" (Letter, Da grave sventura, Aug. 27, 1878 [Desclée, I, 36]). The notion 
was a theoretical denial of the Christian intellectual heritage of European society, so the laicist program of "separation" was a practical effort to cancel out of history the "Catholic nations" which secular history, as well as the Christian heritage, had formed.

If this be a fair statement of the structure of the conflict, the complexity of the issues is readily seen. And the source of the complexity likewise appears. I mean the intimate entanglement of religious, political, and historical elements. The whole movement of the controversy involved a passage from the plane of theological and philosophical anthropology (which is the science of the nature of man as such) to the plane of politics (which is the science of the organized life of man acting with collective purpose in history), and thence a further passage to the plane of history itself, which is a realm of practical realizations on which the force of circumstances and the free will of man stamp a quality of contingence and individuality not to be accounted for by any science. The sectaries made these passages consciously, deliberately, even enthusiastically. Their initial claim was to a new truth for the mind, a novum ius for society, indeed a new wisdom for the whole life of man. And their purpose (to adapt Plato's famous phrase) was to write this new truth large in a new polis, a concrete existential political order, with a definite structure, substance, and ethos. ${ }^{41}$ They had in fact achieved this purpose to no inconsiderable extent. They had destroyed a particular historical form of the Christian polis, and they had created a particular historical alternative, which negated all the various forms that the Christian polis had assumed in European history.

It was this historical alternative in all its determinacy which absorbed Leo XIII's attention and dominated his thought. He saw the new thing in its existential reality before his eyes, just across the Tiber, whence it had come from across the Rhone. He not only saw it; he could, as it were, feel the hot blast of its inimical spirit issuing from its

of "social apostasy" is the basic and central one, rather than "legal separation"; this latter notion is rarely, if ever, mentioned save in connection with the former. The basic problem for Leo XIII was the divorce of religion from society, not the secondary and symptomatic question of separation of Church and state in some juridical sense.

41 "As for the (Italian) government, in this struggle it has openly declared itself to be on the side of 'reason' and against the Christian faith; and it is taking upon itself, as its proper task, that of making the Italian state the patent expression of this 'reason' and 'freedom'" (Dall'alto, ASS, XXIII [1890-91], 197). 
misshapen form and striking him full in the face. To him the Enemy was not simply an aberrant philosophical system, but "genus id reipublicae recens, de quo loquimur." ${ }_{42}$ In Immortale Dei, and indeed in all his utterances, he spoke against this existential thing, not simply against an idea. His purpose was not merely to expose once more the hoary half-truth of an ancient error (for rationalism was an ancient error); more importantly, he willed to dissolve out of existence the new and vicious thing, the concrete polity that confronted him.

The point here is that this preoccupation and purpose impart to all of Leo XIII's utterances on the Church-State problem a powerful polemical bias. As might be expected, the effects of this bias on his total doctrine were manifold, some happy, others less happy. The first effect was an entire clarity with regard to what Leo XIII was against, both in the abstract and in the concrete. To use the pregnant concept, he was against "separation" in the laicist sense. And he delineates with all completeness this type of "separation." He defines it as a principle. He portrays its religio-political ethos. He fully describes its program and the social results of the program. And he not only rejects the principle on which this laicist type of separation rests; he also rejects the concrete political transcription of the principle that was visible to him in the new kind of polity that the Revolution had brought forth in the historic Catholic nations. This clarity and concreteness in the description of the Enemy are most valuable. For one thing, they should prevent anyone from extending Leo XIII's condemnation to any genus reipublicae or to any concrete institutionalization of the Church-State relation which does not coincide with his description of the thing to be condemned.

The exigences of polemic resulted in a second happy clarity. In a sense, the Enemy did the Church a service by his very radicalism. He went to the roots of the matter of the relation between Church and state, between Church and society. Thus he compelled the Church to do the same, that is, to define essential doctrine with a new clarity, to state the theory of the Church-State relation with a new economy, to go below the level of history, on which principle finds more or less contingent application, down to the bedrock of principle itself, on which the truths of transtemporal significance are found.

${ }^{42}$ Encyclical, Immortale Dei, ASS, XVIII (1885), 177. 
In another respect, however, the exigences of the polemic were perhaps less happy in their results. It has been truly said that it is a misfortune to learn one's Christian faith against some error-to learn the doctrine of grace, for instance, against the errors of the Reformers or of Baius. When the truth has to follow the convolutions of heretical categories it tends to lose somewhat its own native contours. In this sense it was unfortunate that Leo XIII should have had to expound the Christian doctrine on the Church-State relation against the error of Jacobinism and in the face of a political realization of this error. This meant at times an alteration of the natively organic structure of the Catholic argument, a manner of statement more adapted to the necessities of the polemic than to the inner demands of the truth itself, a distribution of accents made in view of apologetic effectiveness rather than in view of doctrinal balance. It is not too much to say that the constant brooding presence of the Enemy in all the concreteness of his historical form resulted at times in an interference with the free flow of positive doctrine. In the presence of an enemy one is never free simply to speak out one's own mind; one must calculate effects. When one accepts a challenge one cannot expect always to fight on grounds of one's own choosing. It would not therefore be surprising to find the inevitable stamp of polemic on certain aspects of Leo XIII's teaching. And to the extent that this stamp is found on it, his teaching is "dated," and needs interpretation within the context of its own date.

Before going on to Leo XIII's treatment of the triple issue in the nineteenth-century controversy, it may be appropriate to note one further general characteristic of his thought. As he was against "separation" in the pregnant laicist sense, so he was for "harmony" in the pregnant Christian sense. However, what he was for does not come out quite so clearly as what he was against. This general remark needs precision. The inner structure of the concept of concordia, in terms of the principles that integrate it, is indeed analyzed with all possible clarity. However, there is no comparable clarity in regard of the concrete manner in which these principles are to receive institutional transcription on the historical plane. Here is the discrepancy in clarity. The Pope very clearly condemns genus id reipublicae recens, a particular existent political system; he also rejects the particular institutionalization of the Church-State relation which this polity demanded. On the other 
hand, he does not give his blessing to any particular counter-system, any specific genus reipublicae; in consequence, he does not canonize any positive and determinate institutionalization of the Church-State relation. In a word, his polemic moves onto the historical plane; his doctrine stops short of it. His polemic attacks an existential thing; his doctrine simply states essential principles.

In this respect, Leo XIII is faithful to the genuine tradition of the Church, in contrast to all the pseudo-traditions wherein doctrine has gotten itself mixed up with history. He is faithful too to his great master, St. Thomas. A. P. d'Entrèves concludes his generally excellent study of St. Thomas' approach to social and political problems, including the problem of Church and state, with this statement: "It looks as if, instead of providing us with a complete and elaborate system, he had been concerned with setting forth the principles from which such a system can be constructed. What matters is that the principles should not be betrayed. All the rest is a task for the 'prudent' legislator." 43 The statement is valid for Leo XIII, provided that, when the Church-State problem is in view, the "prudent legislator" is made to include the authority of the Church as well as the civil authority.

Leo XIII himself gives the principle in the matter: "When one comes down from abstractions onto the solid earth of facts, one must indeed be careful not to deny the principles just established; they remain firm. However, in becoming incarnate in factual situations the principles are invested with a stamp of contingency determined by the environment in which they find application." ${ }_{44}$ The statement is explicitly made of the principles that govern the political order. But it is susceptible of generalization to include the principles that govern the Church-State relation; for these principles likewise require to become incarnate in factual situations which are created in considerable part by historical forces. And this descent into the historical inevitably invests them with the stamp of contingency.

Hence it is that the Pope can sally forth quite confidently onto the plane of history, when it is only a matter of attacking a malformed structure there existent. In this case he does not engage himself in rela-

${ }^{43}$ Aquinas: Selected Political Writings, edited with an introduction by A. P. d'Entrèves (Oxford: Blackwell, 1948), Introd., p. xxxii.

${ }^{44}$ Encyclical, Au milieu, ASS, XXIV (1891-92), 523. 
tivities. But the case is different when it is a matter of venturing forth onto that shifting ground in order to lay down with any determinacy the specific lines of the structure desiderated. In this case the commitment would be positive, particular, historical, and to that extent contingent. And the question always would arise, whether and how far the flux of time would respect the validity of the determinate structure to which commitment is made.

The Church, of course, does not totally recoil from commitment to the contingent. To do so would be to fall into angelism, and to refuse the human, and therefore historical, condition to which the Church is bound by all that is institutional in her. Her life is lived in history and therefore involves commitments to its dissolving situations. However, the Church is obliged to insist that her commitments to the contingent should be themselves contingent. In this connection Cardinal Macchi, speaking for Leo XIII, fairly states the pertinent principle:

It is the special property of human institutions and laws that there is nothing in them so holy and salutary but that custom may alter it, or time overthrow it, or social habits bring it to naught. So in the Church of God, in which changeableness of discipline is joined with absolute immutability of doctrine, it happens not rarely that things which once were apposite and suitable become in the course of time out of date, or useless, or even hurtful. ${ }^{45}$

A text of Leo XIII himself must immediately be cited in completion of the foregoing one:

The history of all past ages bears witness that this Apostolic See, to which there have been committed both the teaching office and the supreme rule of the whole Church, has constantly gone forward in eodem dogmate, eodem sensu, eademque sententia. At the same time, it has been wont so to temper its discipline of life that, under safeguard of divine law, it may never disregard the habits and customs of the very different peoples which it embraces. If the salvation of souls demands it, the Holy See will certainly follow the same course today. However, this is not a matter left for settlement to the opinion of private individuals. It must fall to the judgment of the Church. And in this judgment all are to acquiesce. ... ${ }^{46}$

Both of these texts explicitly bear on the internal discipline of the Church herself; the first text concerns the conduct of the apostolate;

${ }^{45}$ Letter (in the form of a Brief), Trans oceamum, ASS, XXIX (1896-97), 659.

${ }^{46}$ Letter, Testem beneolentiae, ASS, XXXI (1898-99), 472. 
the second, the general life of the Christian. Discipline derives from doctrine, but it is directed to life. Therefore the "prudent legislator" will fashion discipline in accord with the relative canons that govern the relation of means to end-the canons of appositeness and suitability, as Rampolla's text has it. However, the final judgment as to what is suitable and apposite is reserved to the authority of the Church.

Both these texts are susceptible of generalization in such wise as to be made relevant to the Church-State relation. Leo XIII exactly defined the principles that govern it-principles both of the theological and of the philosophical order. However, he also made it clear that the Church-State relation is not an end in itself; it is importantly a manner of vivendi disciplina, which looks to the temporal and eternal welfare of man, who is both citizen and Christian. No one has ever insisted more than he did on this matter of finality. Moreover, he exercised his proper right of judgment in abandoning old theories (for instance, he finally wiped out the last traces of curialism) and in altering past policies (for instance, he deliberately caused anguish to the doctrinaire Veuillotistes vieux style, who would have been more Catholic than the Pope). He knew his task to be that of faithfully administering the "lessons of Christian wisdom," but he recognized that fidelity to their wisdom required that they be administered "in a manner accommodated to circumstances of time and social habit." 47 In a word, his sense of the relativities of history was as fine as his sense of the absoluteness of doctrine. It is therefore entirely in accord with his spirit to say that the Church-State relation, insofar as it necessarily becomes incarnate

${ }^{47}$ Letter, Permoti Nos, ASS, XXVIII (1895-96), 4. This sense of history may be illustrated by the following text: "It would indeed be a great error if we were to fail to make abstraction from our own times and customs when it comes to passing judgment on affairs that happened six centuries ago. Actually, regard must be had of the institutions and laws of that day; in particular, one must recall to mind the law of nations under which life was then lived. Whatever may have been the origin and nature of that law, it is a matter of ascertained fact that in those days the authority of the Roman Pontiffs was of great weight even in civil affairs. No objection to this situation was then raised; indeed, both princes and peoples willingly agreed to it. And since the patronage of the Vicar of Jesus Christ was much sought after, it happened not seldom, especially in Italy, that cities had recourse to him as to a public Father; and of their own will they entrusted and commended themselves to his guardian care. As the Apostolic See was the ruler of souls in matters of religion, so it was held to be the bulwark of justice and the protection of the weak against the injurious action of those in power" (Letter, Sicut multa, April 22, 1882 [Desclée, I, 279]). 
in "human institutions and laws," is subject to the law of history stated by Rampolla. These institutionalized forms of the relation tend to become "out of date, or useless, or even harmful." The principles themselves remain-timeless, immutable, constantly applicable, always vital.

So much, then, for a statement of the issues in the nineteenth-century conflict, the source of their complexity, and the general qualities of Leo XIII's teaching -its bias and its balance.

\section{LIBERTY AND AUTHORITY}

On the preliminary level Leo's designated adversary is rationalism, the sectarian philosophy which had rather absurdly dignified itself with the definite adjective, "la philosophie." After the fashion of the Curia he does not give a historical account of the highly ramified rationalist movement. What he gives is a sort of anatomy of the error. Or perhaps the better word would be "skeleton," since "anatomy" implies flesh as well as bones, and the Pope gives only bones. Moreover, only the rationalist theory of freedom is touched, not, for instance, the rationalist epistemology.

For convenience' sake, we may here turn chiefly to Libertas, a leading Encyclical and an ex professo treatment of the subject. In it rationalism appears as the theory that "man, since he is by nature free, ought for that reason to be out from under law (expers legis)"; 48 that "the judgment of the individual conscience is not subject to law (exlex uniuscuiusque conscientiae iudicium)." ${ }_{49}$ It is the theory of the "sovereignty of human reason," interpreted to mean that reason may "refuse the obedience due to the divine and eternal reason, declare itself to be a law unto itself (sui iuris), and constitute itself, in what concerns its individual self, the ultimate principle, source, and judge of truth." ${ }_{50}$

At our distance the extreme individualism and subjectivism of this shallow theory seems entirely naive. The brittle and contracted universe in which such a theory could attract the thinking mind has long since been shattered under the impact of forces more powerful, one must confess, than papal condemnations, namely, the impact of events,

${ }^{48}$ Encyclical, Libertas, ASS, XX (1888-89), 597.

${ }^{49}$ Encyclical, Immortale Dei, ASS, XVIII (1885), 170.

${ }^{50}$ Encyclical, Libertas, ASS, XX (1888-89), 600. 
and the advance of science and scholarship. Other theories, more dangerous because more sophisticated than the simple-minded thing so easily pulverized by Leo XIII, presently hold the field. However, the intellectual and moral climate created by the old-style rationalism still manages to hang around. And within its protecting ambience there survives the original notion of an absolute antinomy between freedom and authority, liberty and law. Authority is still considered to be destructive of freedom by its essence, and not simply by its abuse. Liberty is considered to be of the spiritual order, the order of human personality; whereas law tends to be relegated to the physical order, the order of fact and force. In this sense the problem put to Leo XIII is contemporary.

The structure of the Pope's case against rationalism is simple. And it reveals the characteristic polemic bias. A greatly impious denial had been made; the Pope counters it with a solemn assertion. An equally impious assertion had been made; the Pope counters it with a solemn denial. The whole of his case hangs from this massive twofold proposition: "The net of it is this: by an inherent law (necessitate) it happens that the whole man is in the rightful and continuous power of God; therefore the freedom of man becomes unintelligible, except as it is responsible to God and subject to His will." 51 The impious denial had been of the power of God. The impious assertion had been of the power of human freedom. It had been asserted that the individual free will was single sovereign over private life; that "the people" were the ultimate sovereign over public life; that the Church was no sovereign at all, indeed, that the public power was sovereign over it. Consequently, the Pope's first and last affirmation is of the power of God. His first and last denial is of a power in man that could claim complete autonomy and autarchy, and still pretend to make sense.

From this premise, the power of God over the whole man, the rest of the case rises, or rather, descends. The power of God is resolved into the spiritual power of the Church and the civil power. Both are of God, the civil power through nature, the ecclesiastical power through Christ. As being of God, both powers are sacred, each with a sacredness proportioned to the dignity of its origin and purpose. There is hardly a theme in Leo XIII more frequently iterated than this-the divine

${ }^{81}$ Libertas, ibid., p. 611. 
origin of authority, its consequent sacredness, its status as the rule of freedom. The correlative theme is that the "freedom" which acknowledges no authority over itself is a piece of nonsense. It is not freedom but license, unintelligible in itself, and productive of the unintelligibility which is disorder. Order is the product of authority; the preservation of order demands obedience to authority; and the order thus preserved by obedience is the safeguard of freedom itself.

Libertas hominis is therefore immediately brought into relation with potestas Dei. Only in secondary fashion is libertas paired with lex. The dominant notion always remains potestas, as the principle of restraint on liberty, rather than lex, as the intrinsically complementary principle of liberty. There may be a nuance here, but it is an important one. A more serenely doctrinal exposition would have paired liberty immediately with law, and thence risen to the notion of authority. However, the polemic bias of Leo's thought carries him to an immediate and major stress on the sacredness of authority; he gives relatively little attention to the nature of law.

Leo XIII wrote no special encyclical on law. Yet the problem was enormously important in his day. The nineteenth century, the Political Century, had seen a colossal growth of the legal authority of the state. In Western Europe the last remnants of the feudal order were done away with through the rationalization of the legal order of society, of which the French Civil Code was the leading example. The law and the state together waxed unto unheard-of dimensions. Moreover, intellectual as well as political movements stimulated much activity in jurisprudence; it was in this century that the historical, analytical, sociological, and idealist schools took their rise. Yet, apart from a few paragraphs in Libertas, which represent but a tiny trickle from the great treasury of Scholastic thought, there is no treatise on law in the Leonine corpus. The lacuna may be surprising; it is certainly regrettable, for one important reason.

If Leo XIII had answered at length the question, what is law, and especially, what is human law, one would be in a much better position to answer the question which somehow resists a clear answer on the basis of his corpus as we have it - I mean the question, what is the state? At least this is true for the student who stands within the AngloAmerican political tradition. For us the state is not identically "the 
perfect society," nor the community, nor the nation, nor the people, though it touches all these things as an aspect of them. For us the state is a legal association for limited purposes. It exists in and through law; it exists for law, and for the final adjudication of all the problems that can be answered by law and judicial decision. The purposes of the state are defined by law, and they are confined to such purposes as can be achieved by law. Finally the state's mode of action (and for us the state is essentially action, not entity) is the mode of law, the mode of coercion. The state is the community as juridically organized; or, if you will, it is society under the aspect of its organization for limited action under legal rules. In this sense the state is law.

However, this is a conception of the state that has been developed in the Anglo-American world, out of the substance of the political and legal ideas of the Middle Ages, when, as has often been remarked, there was a great deal of "society" and very little "state," and the two notions were even more distinct than they are among us today. The conception was rather foreign to the later absolutist Continental tradition. It was therefore foreign to the experience of the Papacy, which by the time of Leo XIII had been standing within the absolutist tradition for nearly four hundred years, and had had little, if any, experience of another political and legal tradition which, paradoxically, had more in common with Catholic ideas than the tradition which had grown up in the historical Catholic nations. Actually, Louis XIV stated the essence of the later Continental tradition when he said (if he said): "L'État, c'est moi." (The Jacobins did not alter the substance of the matter when they shifted to the plural and said, "L'Etat, c'est nous.") The great King was not uttering paradox but obvious accepted fact. The King was the state because he was the Power, and the state is the Power. Or, if you will, the state is the nation, and the essence of the nation is its sovereignty, and this sovereignty is concentrated in the King (or later, in "the people").

This is indeed a far too simple allusion to a most important problem, to which a separate and extended discussion must later be devoted. My only point here is that Leo XIII's dominant notion in the field of politics is the notion of potestas, not lex. His primary concern is with the dignity and duties of the Power inasmuch as its origin is from God. $\mathrm{He}$ is less concerned with the nature and scope of law inasmuch as its 
function is the limited ordering of the life of an existent community. In this connection the treatment of law in Libertas is interesting.

The treatment is brief. Three pages are given to the notion of freedom in its necessary relation to the good and the true. Three pages are given to the notion of law. Some thirteen pages are given to a refutation of the rationalist theory of libertas expers legis, in its various institutional expressions. And over this refutation the supreme presiding principle is the majesty of auctoritas iubentis, vetantis Dei. The brief discussion of law presents for the first and last time in Leo's writings the notion of law as an inherent postulate of freedom itself inasmuch as man's freedom is rational. One short paragraph touches the notion of natural law; another, the notion of grace as a liberative principle. Human law receives three short paragraphs, which make two points. The first is the necessary relation of human law to natural law as to its proximate or remote norm. The second is the consequence with regard to what is never long absent from Leo's thought, the civilis legumlatoris munus. The discussion of law leads to the point of preoccupation, the duty of the Power, which is of God, to regard and enforce the law which is likewise of God.

In other words, of the two general canons of human legislation which the Scholastic tradition elaborated Leo XIII adverts to only one, the moral law, or the canon of justice. The other, the canon of consent (secondary indeed, but essential), is here omitted. It may be that the reason lay in the factual situation of the time. In medieval times the mediating principle that organically joined the two canons was the presumption that the sense of justice is resident in the community. Hence it was the duty of the king to obtain consent to his legislation. This consent was the sanction of the justice of law, and, as Carlyle repeatedly points out, the immediate source of its authority, as well as of the authority of the King himself. In the age of les deux Frances such a Christian presumption would perhaps have been presumptuous.

In any event, it would seem that in Leo XIII the Power has come to occupy the central position that in medieval times had been occupied by the People. And the consent of the people does not assume the same importance as a dynamic of human legislation that it had in earlier Christian times. It would seem in fact that Leo XIII tends to emphasize, not the conscience of the people and the need of their consent to 
human legislation, but rather the conscience of the legislator and his obligation to consent to the higher law. This was the notion that had come to the fore in the age of absolutism. In that age the conscience of the king came to be regarded as the source whence justice flowed down to the community, instead of the conscience of the community being the source whence justice accrued to the king's legislation. Correlatively, the stress was laid on the duty of the people to consent to the king's legislation, rather than on the duty of the king to obtain the consent of the people to his legislation. It would seem that Leo's polemic bias led him closer to absolutist conceptions than to the more original Christian and medieval ones.

This centrality of the Power and its duties is evident in the other text in Libertas which deals with the problem of human law, namely, the well-known paragraph on the toleration of evils in society. In this text there is a reflection of the jurisprudential principle that human law is governed by the canon of "possibility," as St. Thomas called it, after Isidore. But one has only to compare the text with the relevant passages of the Summa theologica (I-II, q. 95, a. 3; q. 96, aa. 1-3) in order to see that there has been an alteration of perspectives. First, although the Pope's language is generalized, the context makes it clear that he has in view the particular problem of "the modern liberties." St. Thomas, after Isidore, is discussing a quality that must characterize all human legislation; Leo XIII simply wants to contradict the doctrinaire assertion that "these liberties, even in respect of the moral error they involve, are the highest adornment of our age and the necessary foundation of any polity that may be established, in such wise that, if they were to be taken away, perfect political government would become unthinkable." ${ }_{52}$ St. Thomas' purpose is doctrinal; Leo's, polemic. St. Thomas describes "possibility" as an inherently necessary "condition of law" itself. He derives this condition from two sources; first, from the very nature of law (as directive of a community and therefore functional to its "utility"), and from the mode of action proper to law (which is coercive and therefore minimal in its aspirations); and secondly, from the human condition, as human, as historical, and as verified in a multitude, whose level of virtue is normally not high. There is no "extrinsecism" here. It is not so much a question

${ }^{52}$ Liberlas, ibid., p. 594. 
of law tolerating evils; it is rather a question of the inherently limited scope of law itself, and of its necessary respect for its own nature as well as for the concrete nature of man.

On the other hand, Leo's problem does not arise out of the fairly constant qualities of the human condition as such. The problem is put by a particular historical situation: "the turn taken by events and the minds of men in our age (hic, quo nostra vehitur aetas, animorum rerumque cursus)," in consequence of which there have arisen "special circumstances in the civil community (singularia reipublicae tempora)." Again, Leo XIII is not explaining the limitations set to human law by its very nature and purpose; he is rather complaining about the limitations put upon the public power by sheer conditions of fact. The argument is dominated by his central idea, which is not the law but the Power. This is not the central idea of St. Thomas, in whose treatise the "power of the prince" assumes subordinate place, as simply the source "whence law has its coercive power" (q. 96, a. 5), whereas the dominant idea is the law itself and its finality, "utilitas hominum" (q. 95, a. 3).

Moreover, in Leo's text the whole problem of law seems to be put singly to the public power, for solution by its wisdom alone. There seem to be overtones here of his general view of the public power as the master standing over subjects who are merely subjects, as the quasi-father set over the quasi-family and its quasi-children. ${ }^{54}$ In his polemic situation there was no impulse to have recourse to the classic definition of human law in which Isidore resumed the Roman tradition and inserted it into the Christian tradition: "Law is the order of the people, in virtue of which the elders together with the commonalty have enacted something." The definition is cited and approved by St. Thomas (I-II, q. 90, a. 3, Sed contra). The notion of law as simply the order of the prince was of later development, after the decadence of medieval Christian ideas in the era of absolutism.

Again, in dealing with human law St. Thomas does not advert to the topic of the optimum genus reipublicae, which enters into Leo XIII's treatment. Human law does not take shape in terms of the optimum

${ }^{53}$ Libertas, ibid., pp. 609, 610.

5 There are a number of texts to this effect; e.g., in Libertas it is said to be the duty of government "to rule the people kindly and with a manner of paternal love" (ibid., p. 605). 
but of the bonum. Its purpose is modest-simply to ensure that minimum of actualized morality which is necessary for the existence and functioning of society. ${ }^{55}$ The perilous notion of the optimum is thrust into Leo's discussion of human law as a part of his contradiction of the adversary. ${ }^{56}$ The adversary said that the modern liberties in the laicist sense are an index and a necessity of the "best" polity. No, says the Pope, they are erroneous in their premises and evil in their social consequences; therefore the best that can be said of them is that they are tolerable.

Finally, one does not find in St. Thomas the suggestion of a double situation, one per se and the other per accidens. As if per se the situation would be a sort of Golden Age, in which the disciplina cogens metu poenae, as St. Thomas calls human law (I-II, q. 95, a. 1), would completely enact and enforce all the imperatives of the natural and evangelical laws. And as if anything short of this Ideal Republic of Truth and Justice were somehow a per accidens situation, tolerable in fact, intolerable in principle. Such a construction is entirely alien to the realism of St. Thomas, whose theory of human law is firmly built upon the existential nature of man, its sinfulness and its historicity. In consequence of the nature of man and in further consequence of its own nature as a "discipline that is coercive by fear of punishment," human law per se and not simply per accidens "falls short of the eternal law" (q. 96, a. 2, ad 3m).

Actually, St. Thomas does not attempt to give a detailed description of the legal code that ought to rule society. $\mathrm{He}$ is content to give three principles: that human law finds its ultimate norm and the primary source of its obligation in the higher law of God; that it finds its proximate norm in the human condition of man and the historical state of particular societies; and that, when conditions of popular freedom obtain, in his favorite royal and political (popular) regime, the sanction and consent of the people likewise conditions the justice and obligation of human law. The application of these principles in

${ }^{65}$ Cf. J. Messner, Social Ethics (Herder: St. Louis, 1949), pp. 150-67.

${ }_{56}$ The notion is perilous in that it might lead to erroneous conclusions. For instance, it is one thing to say, with Leo XIII, that the fewer evils there are in a society, the better the society is; that is a truism. It would be quite another thing to say that the more laws there are to repress evils in a society, the better the society is; that is no sort of proposition in Scholastic jurisprudence. 
a determinate society is left to the prudence of the legislator and the will of the people. The resultant legal code will always be imperfect from the standpoint of truth and justice; but the situation it establishes will obtain per se, in consequence of the principles it embodies. For the rest, a powerful dynamic of change for the better is present: the natural sense of justice inherent in human reason, and the leaven of the Gospel and its grace deposited in the soul of man by the Church. However, this dynamic of change is operative in the first instance on the people, not on the legislator. The moral and spiritual forces of the popular conscience must first be awakened, before human legislation can make for higher goals. St. Thomas' concept of law and society is not that which later prevailed in the absolutist era.

As a matter of fact, one does not find in Leo XIII this notion of a double situation, one per se (the Ideal), the other per accidens (the lamentable Real). Naturally enough, since this concept is foreign to the tradition. There is, of course, the well-known sentence:

However, if on account of special circumstances in the civil community it happens that the Church gives assent to certain of the modern liberties, not because she per se prefers them but because she judges it practically suitable to the end in view (expedire) that they should be permitted, nevertheless, if times were to change for the better, she would surely employ her freedom; and by persuasion, exhortation and entreaty, she would endeavor, as she ought, to accomplish the function committed to her by God, which is to have care for the eternal salvation of men." ${ }^{57}$

This is not the most lucidly consequent sentence that Leo XIII ever wrote; in fact, the whole paragraph does not reveal him at his best in consecutive argument. However, it is entirely clear that he is not drawing a comparison between a concrete, hypothetical, per accidens situation and an abstract, thetical, per se situation-between a factual situation in which the modern liberties unfortunately exist, and an ideal situation in which they happily would not exist. The comparison is between two historical situations - two hypotheses, if you will.

One is the existence of genus id reipublicae recens, in which the modern liberties are predicated on explicitly rationalist premises and function in the determinate laicist sense. As the ensuing sentence states, the ${ }^{57}$ Libertas, ibid., p. 610. 
basic premise is that what is called "truth" and what is called "error" are quite on the same footing, since both equally issue from equal "freedoms," from equally "free consciences," and by virtue of that simple fact both possess the same "right" to call themselves "truth." In a word, what is freely thought or said or done is truly and justly thought and said and done (whether it is or not), because the thought, the word, the deed, are free. This, of course, is patent nonsense, hardly worthy of the village atheist. Again, the modern liberties in the laicist sense function in a manner that climaxes the absurdity of their theory. They create a situation, as the concluding sentences indicate, in which there is unlimited freedom for everybody's ideas and everybody's action-except for Catholic ideas and for the action of the Church. This is tolerance's own intolerance; and it is more rigid, the Pope says, than any that can be imputed to the Church.

The other situation is likewise historical; it would come about versis in meliora temporibus. Characteristically, Leo XIII does not describe its futuribly existential reality. He does not say whether, and on what premises, and to what extent, and under what safeguards, and with what concrete social effects the modern liberties might, or might not, obtain in it. As I said before, he clearly delineates the thing he is against, not the thing he is for. However, in this passage as iteratedly elsewhere, he makes clear the principles he is for.

First, he is for the principle that human freedom stands under the authority of a truth that is not of its own creation, and that it is inherently subject to a law and an order likewise not of its own creation. Secondly, he is for the principle of the freedom of the Church to fulfill her divine mission in her own way, by the free ministry of the Word. (His cardinal objection to the existent situation is based on its violation of these two principles.) Thirdly, he is for the principle that human law, at the same time that it is bound to divine law, must have regard for "the heavy weight of human infirmity," and for the given historical situation. Fourthly, as he has previously said and later again says, in any historical situation whatever, human freedom remains essentially a power of doing what is right and good, and therefore whatever "liberties" a man may have in society must be turned to the service of truth and goodness: "For every freedom is to be considered legitimate insofar as it creates greater possibilities of virtuous action; 
otherwise-no." ${ }_{58}$ These are the principles. Their penetration into society will operate a historical "change for the better." But what the precise contours of the new situation will be-what, for instance, its political institutions will be- the Pope does not say. He is the prophet of the truth, not of the future.

The purpose here was not to explore the problem of the modern liberties or of tolerance. The inquiry concerned the relations of freedom and authority, liberty and law. And the essential point was that Leo XIII's doctrine passes through the refracting atmosphere of an all-enveloping polemic, and in consequence, it emerges somewhat foreshortened, with those accents which are appropriate to the requirements of the polemic. The major accent falls on the sacredness of authority, as being of God. From this follows the necessity that freedom be subject to the authorities that are of God. Again, in the treatment of human law, the primary accent falls so heavily on the eternal law of God as its necessary norm, that the secondary norm, the "living law" of the people (as more recent jurisprudents call it, after Ehrlich), fails to assume the importance it has in the balanced Scholastic theory. Similarly, the emphasis falls so heavily on the public power and its duties in regard of the law of God, that the ancient Roman and Christian idea of the people and its right of sanctioning human law tends to be lost from view.

This only means, of course, that Leo XIII, especially in Libertas, was not writing a scholarly treatise on freedom and authority, liberty and law. Not the nuances of theory but the needs of the time were his dominating concern. One who wants to know the full tradition in all its balance and sophistication will go to the massive documentation that records it. In Leo XIII one will find only a limited arsenal of weapons, as it were, with which to battle a particular adversary. The only mistake would be in confusing the Scholastic and the papal purpose.

What then was the papal purpose? It was single and simple. It was to oppose the secularization of politics. This phrase will do to cover the whole movement, remote in its origins, which had received a powerful impulse from the Revolution, until it had become a flood-tide that threatened the whole of what once was Christendom. The threat was

${ }^{68}$ Libertas, ibid., p. 612. 
twofold. First, the tide threatened to wreck the traditional structure of politics. This structure had been fashioned in accord with the traditional concept of Christian man, whose life is lived in two orders, between which harmony must reign. There is the spiritual order, whose perspectives are those of man's eternal destiny, of which the Church is the representative; and there is the temporal order, whose perspectives are those of an earthly peace and justice, of which the political community is the representative. The new movement aimed at secularizing the structure of society by obliterating this differentiation of orders, by reducing the whole of man's social life to sheerly political life, and then subjecting it to the single direction of the power that is political. Secondly, the powerful new tide threatened to wash out the traditional substance of Western society. This substance had been furnished by the confluence of the natural intellectual patrimony of the human race, whose origins were in classical antiquity, and the supernatural patrimony of truth with which the Church had been endowed by Christ. The new movement sought to secularize the substance of society by denying the social relevance of the Christian patrimony (a denial chiefly symbolized by the exclusion of the Christian religion from education), and by establishing the whole social process, in all its forms and institutions, on the single basis of the axioms of rationalism and scientism.

In the light of this movement towards the secularization of politics in a double sense the whole structure of Leo XIII's doctrine, and his selection of themes, and his distribution of accents become clear. So, for instance, in regard of the theme just now treated-freedom and authority, liberty and law. The Pope's dominant aim had to be to join firmly together what men had put asunder. He had to join the power that is in man to the power of God, from which it had been cut loose. Individual freedom, man's power of direction over his personal life, had to be brought under God's sovereignty, to which in the first instance the direction of man's life belongs. And the public power, which has direction over the social life of man, had in its turn to be dethroned from its presumed omnipotence, and made subject to the power of God, to which also belongs original and final authoritative rule over society. The secularization of politics had ensued on the assertion of man's absolute individual autonomy, as prolonged into 
the assertion of the absolute autonomy of political power. The first thrust of opposition to this secularization therefore took the form of the counter-assertion: "The net of it is this: the whole man is in the rightful and constant power of God; consequently, the freedom of man makes no sense, except as it is responsible to God and subject to His will." This was the prophetic assertion with which the Holy See sought to stem the tide of history.

Leo XIII reiterated this truth in every possible context. It is, of course, a truth of the religious order, metapolitical, metahistorical. But there was the further problem of its articulation in political and social terms; for, as has been said, an activist party was engaged in articulating its own "new truth" in a new structure of politics and a new substantive content of society. It remains therefore to follow Leo $\mathrm{XIII}$ as he himself followed the adversary onto the ground where ideas have their consequences. It remains, in other words, to see the lines of his argument for the tradition of the two powers and two societies against what he called the "new regalism," and also to see his argument for traditional "Christianity" in the pregnant sense against the new religion of laicism. These were the two further issues in the nineteenthcentury conflict. As they are unfolded, it may be that further clarification and development will accrue to some of the things said in this present article. 